10)/1958

Report No.

WR-B-91-9
U.S. Department of wnergy Office of Inspector General
Release Date:

September 27, 1991

Report on

\title{
Audit of New Mexico Gross Receipts Taxes Paid by DOF Field Office, Albuquerque Management and Operating Contractors
}

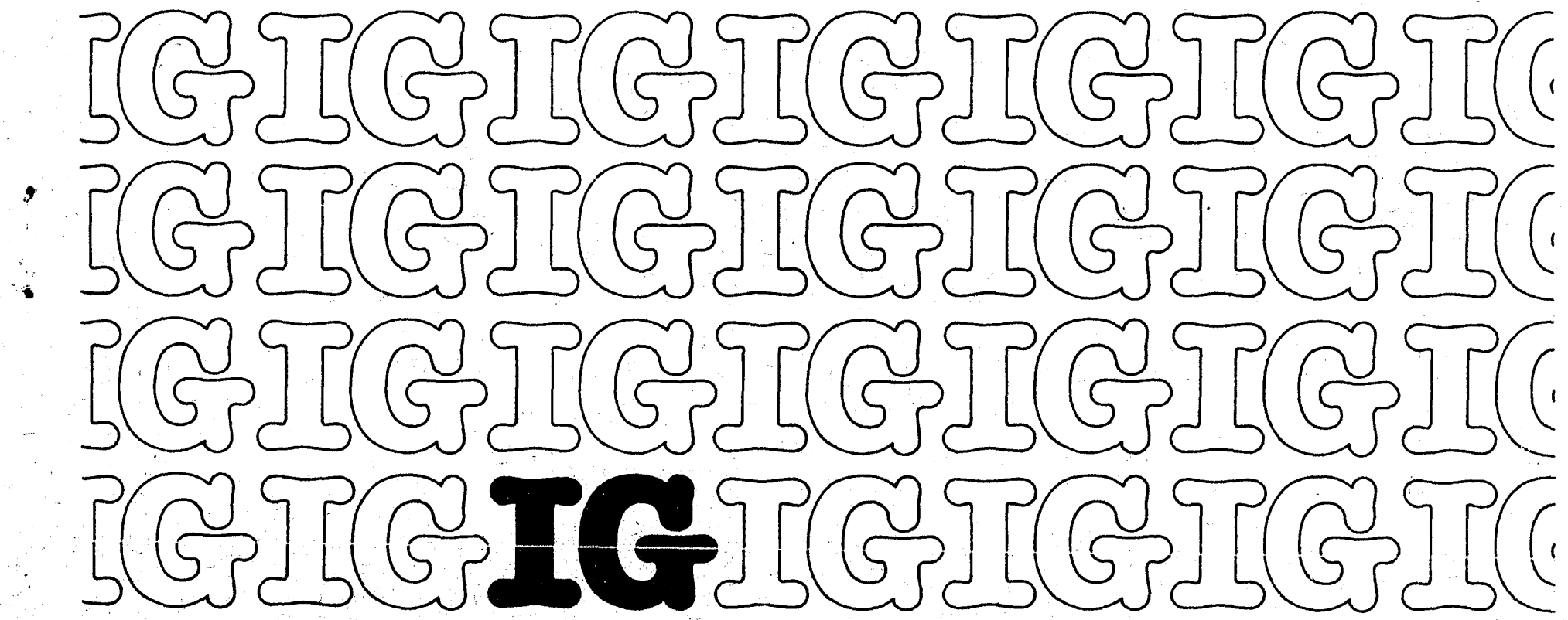


Oak Rldge, Tennensee 37831 
WR-B--91-9

TI92 002207

U.S. DEPARTMENT OF ENERGY

OFFICE OF INSPECTOR GENERAL

\author{
AUDIT OF NEW MEXICO GROSS RECEIPTS TAXES \\ PAID BY DOE FIELD OFFICE, ALBUOUEROUE \\ MANAGEMENT AND OPERATING CONTRACTORS
}

Report Number: WR-B-91-9

Western Regional Audit Office

Date of Issue: September 27, 1991

Albuquerque, NM 87115

\title{
MASTER
}




\section{AUDIT OF NEW MEXICO GROSS RECEIPTS TAXES \\ PAID BY DOE FIELD OFFICE, ALBUOUEROUE \\ WANAGEMENT AND OPERATING CONTRACTORS}

TABLE OF CONTENTS

PAGE

SUMMARY.................. 1

PART I - APPROACH AND OVERVIEW......... 2

Purpose and Objectives.......... 2

Scope and Methodology........... 2

Background................. 3

Observations and Conclusions...... 3

PART II - FINDINGS AND RECOMMENDATIONS...... 5

1. Westinghouse and Ross Did Not Issue Resale of Services

certificates.............. 5

2. Sandia Substantiated Deductions And Exclusions From Its Gross

Receipts with Estimates....... 8

3. Westinghouse Improperly computed

Its $\mathrm{Tax}$ Liability ......... 10

PART III - MANAGEMENT ANÑ AUDITOR COMMENTS... 12 
U.S. DEPARTMENT OF ENERGY

OFFICE OF INSPECTOR GENERAL OFFICE OF AUDITS

\begin{tabular}{c} 
AUDIT OF NEW MEXICO GROSS RECEIPTS TAXES \\
\hline PAID BY DOE FIELD OFFICE, ALBUOUEROUE \\
MANAGEMENT AND OPERATING CONTRACTORS
\end{tabular}

Audit Report Number: WR-B-91-9

September 27,1991

\section{SUMMARY}

Cost reimbursable Management and operating (M\&O) contractors performing services for the Federal government in New Mexico must pay gross receipts tax pursuant to the state's Gross Receipts and Compensation Tax Act (Gross Receipts Act). The purpose of this audit was to assess whether the Department of Energy (Department) and its M\&O contractors had established controls to assure that the M\&O contractors accurately computed their tax liability and issued nontaxable transaction certificates to vendors when appropriate.

The audit disclosed that (1) Westinghouse Electric Corporation (Westinghouse) and Ross Aviation, Inc. (Ross) did not issue Resale of service tax exempt certificates: (2) Sandia National Laboratories (Sandia) substantiated deductions and some exclusions from its gross receipts with estimates; and (3) Westinghouse improperly computed its tax liability on reimbursed costs. These conditions occurred because DOE Field office, Albuquerque (AL) did not have the necessary procedures to review its $M \& O$ contractor practices regarding gross receipts taxes. Furthermore, the M\&O contractors' practices were not consistent with state law.

The Manager, $A L$, agreed to establish controls to insire that its M\&O contractors (1) have procedures in place to issue all tax exemption certificates available to them and to effect the proper computation for gross receipts tax, and (2) establish procedures that incorporate a method of substantiating claimed deductions and exclusions from gross receipts with source documents.

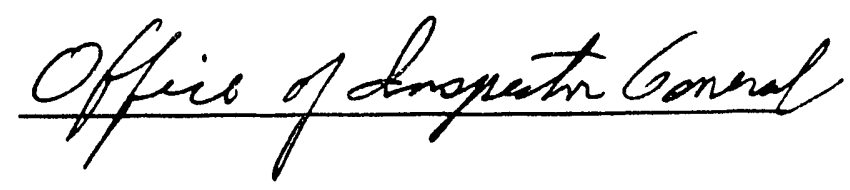


PART I

APPROACH AND OVERVIEW

\section{PURPOSE AND OBJECTIVES}

The purpose of the audit was to assess whether the Department and its M\&O contractors had established controls to assure that the contractors accurately computed their tax liability and issued certificates when appropriate. The audit objectives were to determine if the Department and its M\&O contractors (1) incurred unnecessary New Mexico gross receipts tax, and (2) complied with laws and regulations concerning their taxes.

\section{SCOPE AND METHODOLOGY}

Our audit covered $A L$ and the following $A L$ M\&O contractors: Sandia, Ross, and Westinghouse. Field work was done between April 1990 and January 1991. We limited the review of tax returns to the tax periods October 1989 through June 1990 and nontaxable transaction certificates to the period January 1990 through June 1990.

In addition to interviewing $A L$ and M\&O contractor personnel, the review covered the following significant administrative and accounting controls relating to gross receipts tax:

- Department and AL regulations and policies;

- New Mexico Taxation and Revenue Department Regulations;

- M\&O contractor procurement policies, procedures, and practices for the issuance of certificates;

- M\&O contractor accounting policies, procedures, and practices for the calculation of New Mexico gross receipts tax; and

- M\&O contractor tax returns and supporting documentation for deductions and exclusions claimed.

The audit complied with generally accepted government auditing standards which included tests of internal controls and compliance with laws and regulations to the extent necessary to satisfy the objective of the audit. Because our review was limited, it would not necessarily have disclosed all internal control weaknesses that may have existed. 
We discussed our findings with representatives from AL's office of Chief Counsel, Contracts and Procurement Division, and Financial Management Division during an exit conference on September 19, 1991.

\section{BACKGROUND}

The State of New Mexico established the Gross Receipts Act on July 1, 1967. The Gross Receipts Act authorized the state to impose a tax on the gross receipts of persons who perform services or sell property in New Mexico and have a business location in the state.

Contractors doing work for the Federal government in New Mexico must pay New Mexico gross receipts tax. In March 1982, the U.S. Supreme Court unanimously decided that New Mexico gross receipts tax could be applied to the funds received by government contractors in New Mexico for payment of salaries and internal costs. In December 1982, the Department, along with eight Federal agencies and the New Mexico Taxation and Revenue Department (TRD) agreed to facilitate the equitable administration and enforcement of the revenue laws of the state of New Mexico (Agreement).

The Agreement required government contractors to follow state tax laws, that allowed for deductions and exclusions from their taxable gross receipts (funds reimbursed for meeting salaries and internal costs). For example, a contractor could deduct the amount reimbursed for the purchase of tangible personal property tnat is transferred directly to the government. A contractor could also exclude the amount reimbursed for services performed outside New Mexico.

The Agreement also established the use of certificates for the purpose of exempting government contractors from paying gross receipts tax to vendors on purchases of goods and some services. The state provided a different type of certificate for each type of purchase. For example, the state's Type 15 (Federal Contractor) certificate is used when a contractor purchases tangible personal property for the Federal government. Similarly, the state's Type 5 (Resale of Services) certificate is used when a contractor purchases a service for resale.

\section{OBSERVATIONS AND CONCLUSIONS}

According to the Gross Receipts Act, M\&O contractors doing work for the Department in New Mexico must pay gross receipts tax on funds received from the Department. M\&O contractors may also issue certificates to vendors to exempt themselves from paying gross receipts tax on purchases of goods and services. TWO M\&O contractors (Ross and Westinghouse), however, did not exempt themselves from such taxes when purchasing services performed in 
New Mexico and resold to the government. As a result, Ross and Westinghouse paid gross receipts tax of approximately $\$ 402,500$, some or all of which they could have avoided.

Furthermore, Westinghouse did not compute its gross receipts tax on reimbursed costs according to the Gross Receipts Act and underpaid the state about $\$ 165,000$. Sandia also had a problem with compliance of the Gross Receipts Act. Sandia used estimates to substantiate deductions and some exclusions from its gross receipts instead of invoices, purchase orders, and contracts. In the event of a tax audit, sandia could be required to substantiate its deductions and exclusions and possibly become liable for additional tax, plus penalties and interest. These instances occurred because neither $\mathrm{AL}$ nor the M\&O contractors had established adequate internal controls.

Our findings relating to M\&O contractors (1) not issuing Resale of Services certificates to veridors performing services in New Mexico; (2) incorrectly computing their tax liability on gross receipts; and (3) using estimates to substantiate deductions and exclusions from gross receipts represent material internal control weaknesses which AL should include when preparing its year-end assurance memorandum on internal controls. 


\section{PART II}

\section{AUDIT FINDINGS AND RECOMMENDATIONS}

\section{Westinghouse And Ross Did Not Issue Resale of Services Certificates}

\section{FINDING}

The state permitted taxpayers to issue Resale of services certificates to vendors who provide services for resale in New Mexico; however, Westinghouse and Ross did not issue these certificates. Officials at Westinghouse and Ross did not know the certificates could be issued when procuring these services. Further, AL did not have the necessary procedures in place to review contractor gross receipts tax practices. Westinghouse and Ross paid gross receipts tax of approximately $\$ 402,500$, some or all of which could have been avoided if $A L$ had advised Westinghouse and Ross to issue the certificates.

\section{RECOMMENDATIONS}

We recommend that the Manager, AL:

- Direct Ross to establish controls that will ensure Resale of Services certificates are issued when appropriate. We do not have a recommendation for Westinghouse because Westinghouse established controls for the issuance of Resale of Services certificates during the course of our fieldwork.

- Establish administrative procedures to ensure that $A L M \& O$ contractors issue certificates when appropriate and comply with the Gross Receipts Tax Act. This recommendation also applies to Findings 2 and 3 .

\section{MANAGEMENT COMMENTS}

The Manager, AL concurred with our recommendations. AI has established an action plan to fully implement the recommendations.

\section{DETAIIS OF FINDING}

Under section 7-9-48 of the Gross Receipts Act, contractors could have issued Resale of Services certificates to vendors for services pertormed in New Mexico and resold to the government. contractors could have issued the certificates if (1) they resold the service in the ordinary course of business: (2) they separately stated the value of the service in the subsequent resale; and (3) the receipts from the resale were subject to the gross receipts tax. 
In 1989 , Sandia requested a ruling from the TRD for issuing Resale of services certificates to vendors who were doing research and development work in New Mexico for Sandia. The TRD issued Ruling 440-89-01 which stated that Sandia could issue Resale of Services certificates to vendors providing research and development services that were, "resold" to the Department under the provisions of section 7-9-48. Sandia interpreted the TRD Ruling to apply to all services and notified the TRD of its intention to issue Resale of Services certificates to vendors performing services in New Mexico. The AL office of Chief Counsel agreed with Sandia's interpretation to issue Resale of Services certificates when appropriate. Sandia started issuing Resale of Services certificates in January 1990 for services performed in New Mexico.

Westinghouse and Ross did not issue Resale of services certificates. Instead, they paid gross receipts tax to vendors because they did not know the certificates could be issued when procuring services. During the six month period January 1990 through June 1990, westinghouse paid gross receipts tax to vendors of approximately $\$ 399,000$ on 35 of 68 service procurements. In the remaining 33 procurements, vendors did not include gross receipts tax in their invoices or submit invoices for pavment during the period. During that same six month period, Ross paid gross receipts tax to vendors of approximately $\$ 3,500$ on a total of 43 service procurements.

Al neither had the necessary administrative controls for reviewing its M\&O contractor practices concerning gross receipts taxes, nor did they inform their m\&O contractors of the applicability of Resale of Services certificates. AL performed Contractor Procurement System Reviews (CPSR); however, we found nothing in the CPSR methodology that evaluated M\&O contractor procedures for issuing certificates. AL was aware that sandia began issuing Resale of Services certificates in January 1990 but did not inform westinghouse and Ross of their applicability. In addition, $A L$ has never ensured that its M\&O contractors followed state gross receipts tax regulations for government reimbursed costs. An AL Financial Management Division official stated that they were responsible for seeing that $A L$ M\&O contractors had controls in place that would ensure that taxes were computed according to the Gross Receipts Tax Act. However, AL had never conducted M\&O contractor reviews of gross receipts tax practices.

By not issuing Resale of Services certificates, Westinghouse and Ross paid gross receipts tax on the procurement of services performed in New Mexico. Over the six month period, January 1990 through June 1990, Westinghouse and Ross paid gross receipts tax totaliing $\$ 402,500$. If these service procuroments met the tests for issuing Resale of services certificates, some or all of the $\$ 402,500$ could have been avoided. 

Westinghouse has since established procedures to issue
Resale of services certificates on the purchase of services. The procedures required all westinghouse buyers to begin the immediate employment of Resale of services certificates. 


\section{FINDING}

state tax filing instructions required taxpayers to substantiate deductions from gross receipts with source documents such as invoices, purchase orders, and contracts. source documents were also required to substantiate exclusions from gross receipts. Sandia used estimates to substantiate deductions and some exclusions from its gross receipts. Sandia used estimates because it relied on a 1982 verbal agreement with the TRD and $A L$ had not established controls to ensure that its contractors complied with state tax laws. In the event of a TRD audit, sandia could be raquired to substantiate these deductions and exclusions with source documents. Otherwise, the TRD would disallow the deductions and exclusions and assess tax, plus penalty, and interest.

\section{RECOMMENDATION}

We recommend that the Manager, AL direct Sandia to develop a rationale, and process to substantiate any claimed deductions and exclusions from gross receipts with source documents.

\section{MANAGEMENT COMMENTS}

The Manager, AL concurred with our recommendation. AL has taken steps, through its oversight function, to insure that Sandia establishes procedures that incorporate a method of substantiating any claimed deductions or exemptions from the gross receipts tax.

\section{DETAILS OF FINDING}

Taxpayers must substantiate deductions and exclusions from their gross receipts. New Mexico's gross receipts filing instructions required deductions from gross receipts to be substantiated with documents such as invoices, purchase orders, and contracts. The instructions also stated that the taxpayer should have the necessary documentation in their possession. TRD officials stated that exclusions from gross receipts must also be substantiated.

Sandia used estimates to substantiate deductions and some exclusions from its gross receipts. Per a 1982 verbal agreement with the TRD, sandia estimated its deductions from gross receipts for (1) the cost of tangible personal property purchased for the Government and not used internally, and (2) the cost of products manufactured internally and transferred to the Government. Sandia also estimated its exclusions from gross receipts for the cost of purchases for services performed outside of New Mexico, and for material or property rot used in New Mexico. Sandia based its deductions and exclusions on estimated percentages applied to current month costs incurred. The percentage 
estimates were provided by case managers through an annual questionnaire.

Sindia used estimates to substantiate its deductions and exclusions because it relied on the verbal agreement with TRD. In addition, $A L$ had not established procedures to ensure that $A L$ contractors complied with the Gross Receipts Tax Act. AL had never conducted reviews of it.s M\&O contractors tax practices.

The TRD could require sandia, within 60 days of notice, to provide source documents to support its estimated deductions and exclusions of approximately $\$ 72$ million for the tax periods october 1989 through June 1990. Otherwise, the TRD would disallow tivese ceductions and exclusions and assess tax, plus penalty, and interest. The TRD notified Sandia in December 1990 that sandia had been selected for an audit. An entrance conference was held at Sandia on February 7, 1991 and Sandia officials stated that fieldwork would commence in June 1991. 
FINDING

The Department's Agreement with the TRD stipulated that contractors shall determine their tax liability according to the state tax laws. However, westinghouse improperly computed its tax liability because it did not include an award fee as a taxable receipt, did not claim allowable exemptions, and made clerical errors in computing its taxes. Westinghouse made these mistakes because its procedures were insufficient to ensure an accurate tax computation and $\mathrm{AL}$ had not established procedures to ensure that its contractors complied with state tax laws. Westinghouse underpaid the state of New Mexico by approximately $\$ 165,000$ in gross receipts tax for the period tested. westinghouse has since instituted procedures to properly compute its gross receipts tax liability.

\section{RECOMMENDATION}

We recommend that the Manager, AL conduct a follow-up review of the Westinghouse procedures instituted for computing its gross receipts tax.

\section{MANAGEMENT COMMENTS}

The Manager, AL concurred with our recommendation. AL is now in the process of reviewing Westinghouse's procedures for computing gross receipts tax.

\section{DETAILS OF FINDING}

The Dexartment's Agreement, with the TRD, stipulated that the gross receipts tax liability of corporations, who were prime contractors to the Department, shall be determined according to the provisions of the Agreement and any other applicable provisions of the New Mexico revenue laws. Gross receipts included the total amount of money received from performing services in New Mexico (Section 7-9-3(F)), and such receipts were taxable. Conversely, receipts from services performed outside the state of New Mexico were exempt (Section 7-9-13.1).

Westinghouse improperly computed its tax liability. It did not include an award fee as a taxable receipt, did not claim allowable exemptions, and made errors in computing its taxes. Although Westinghouse paid $\$ 1.999$ million in tax, it did not pay tax on a $\$ 1.2$ million award fee receipt, did not claim axemptions from receipts for services performed outside $N$ w wexico, and made clerical errors in computing its tax liability.

Westinghouse made these mistakes because it lacked sufficient procedures to ensure that its tax liability was accurately computed. A Westinghouse official stated that procedures for calculating gross receipts tax were incomplete and there was no supervisory review of the tax computations. This 
lack of ndministrative controls led to errors and miscalculations of Westinghouse's gross receipts tax.

Westinghouse underpaid gross receipts tax to the state of New Mexico for the tax periods october 1989 through June 1990. milhough westinghouse paid total gross receipts tax of $\$ 1.999$ approximately $\$ 2.164$ million. As such, Westinghouse underpaid its taxes by approximately $\$ 165,000$.

Westinghouse has since instituted procedures to properly compute its gross receipts tax. Westinghouse officials stated that award fees were now being included in its calculations and exemptions were being claimed for the cost of services performed outside of New Mexico. Westinghouse also stated that calculations were cross-checked for accuracy and completeness. 
Tn responding to our draft version of this report, the Director, Contracts and Procurement Division agreed to establish controls to be carried out through AL's management function. A summary of management's comments and our replies follows.

\section{Westinghouse and Ross Did Not Issue \\ Resale of Services certificates}

Management comments. AL concurred with the recommendations and agree? to direct Contractors to prepare procedures, subject to $A L$ review and approval, to provide for the issuance, as appropriate, of all certificates available to them. AL has established an action plan to fully implement the recommendations for this finding.

Auditor comments. We believe that AL's planned actions are responsive to the recommendations.

\section{Sandia substantiated Deductions and Exclusions From Its Gross Receipts With Estimates}

Manager ent comments. AL concurred with the recommendation and agreed to insure, through its oversight function, that sandia would establish procedures that incorporate a method of substantiating any claimed deductions or exemptions from the gross receipts tax. AL audit procedures will include review of contractor compliance with such procedures.

Auditor comments. We believe that AL's planned actions are responsive to the recommendations.

\section{Westinghouse Improperly computed Its Tax Liability}

Management comments. AL concurred with the recommendation and agreed to establish controls to be carried out through its oversight function. The control will be in the nature of DOE review/audit procedures to insure that the contractor has in place procedures to effect proper computation of gross receipts tax. As of september, 16, 1991, AL was reviewing Westinghouse's procedures for computing gross receipts tax.

Auditor Comments. We believe that AL's planned actions are responsive to the recommendations. 

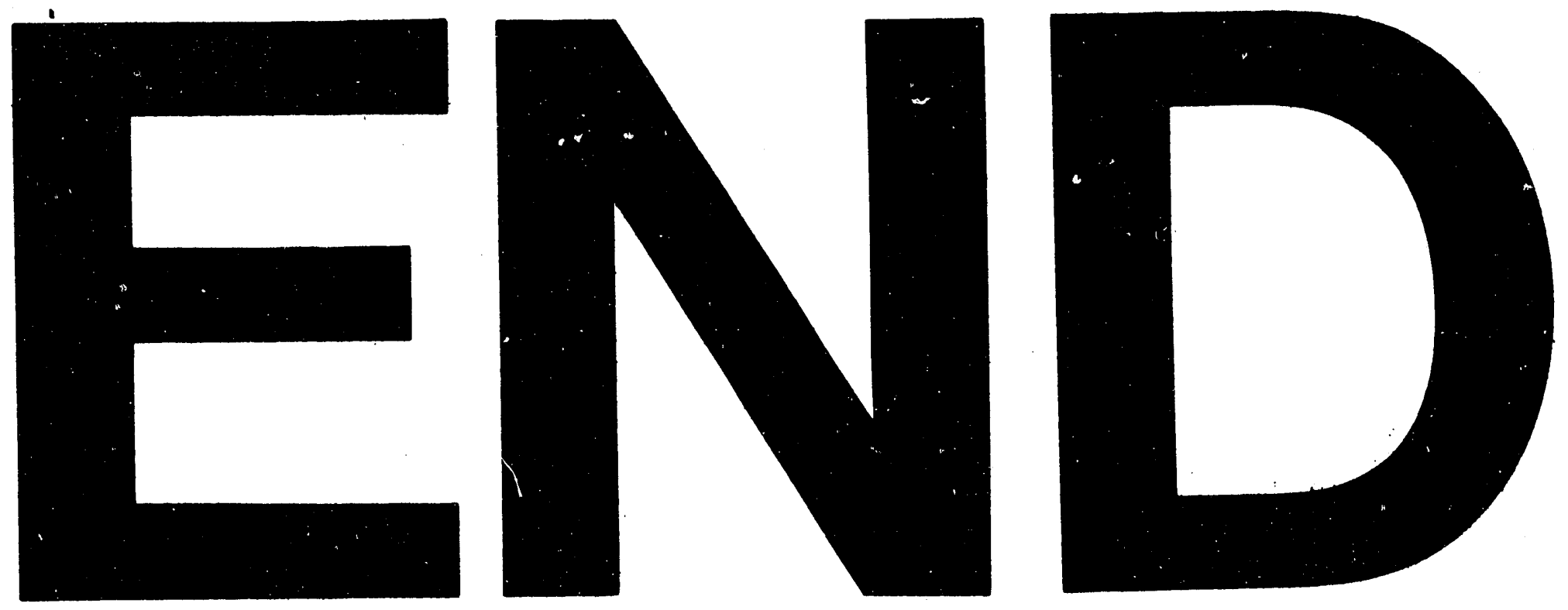

4.

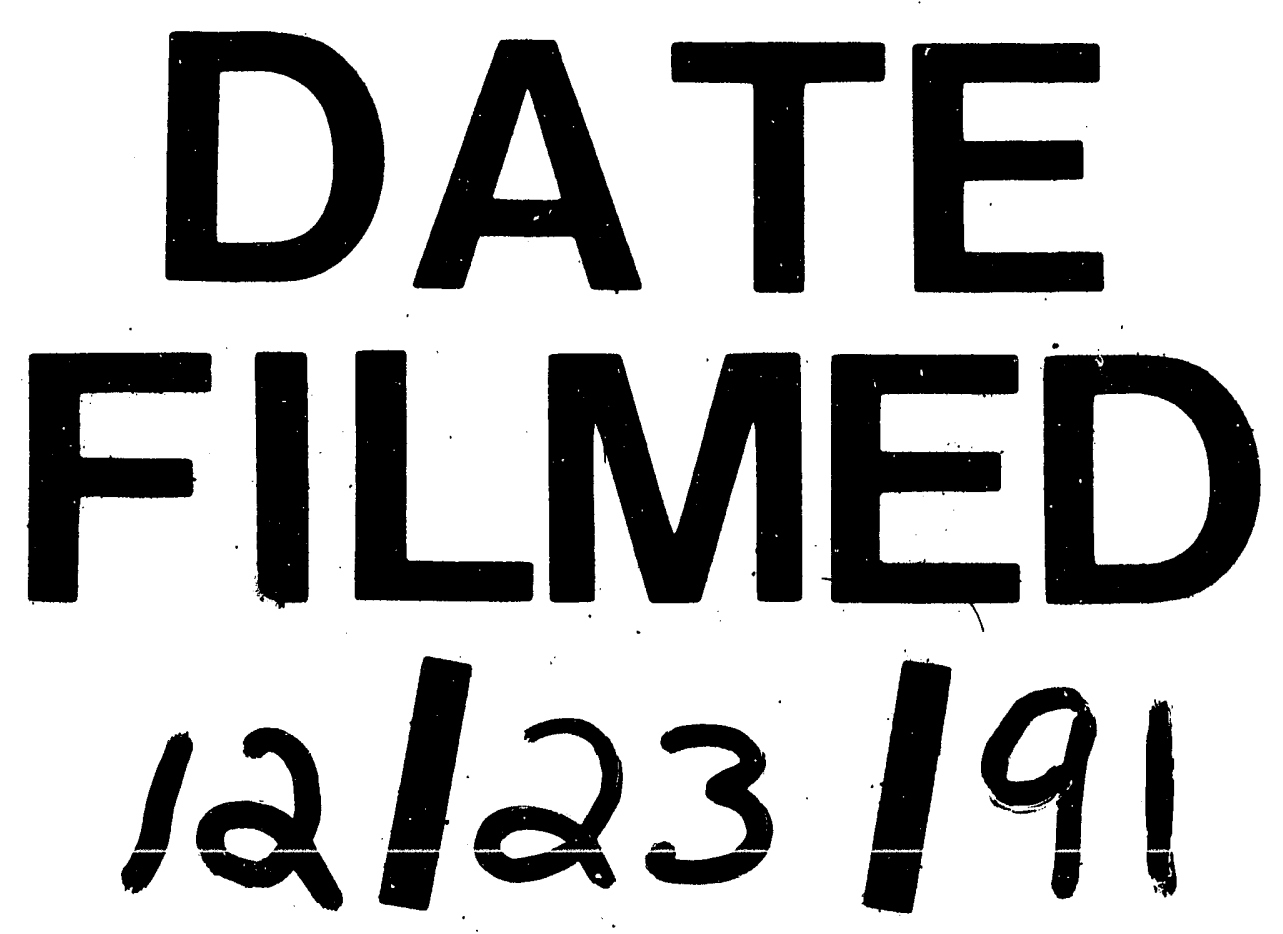

$I$ 
